\title{
CLEOPATRA'S TRANSLATIONAL POWER
}

\section{EL PODER TRASLACIONAL DE CLEOPATRA}

\author{
Bess R. H. Myers
}

University of Illinois, Urbana-Champaign

\section{ABSTRACT}

When Plutarch introduces Cleopatra in the Life of Antony, he notes that though she was not beautiful, she charmed those around her with her ability to speak an abundance of languages. In this passage, he associates the word bermeneus, «translator», with Cleopatra. Analyzing all appearances of hermeneus in Plutarch's corpus reveals how, on the surface, Cleopatra's association with the translator figure reinforces her reputation as a femme fatale, though this association gestures to a three-dimensional character who resists the two-dimensional bounds of extant written accounts —including Plutarch's own.

Key words: Translation, translators, hermeneus, Cleopatra, Plutarch, gender studies

\section{RESUMEN}

Cuando Plutarco presenta a Cleopatra en la vida de Antonio, nota que, aunque no era hermosa, encantó a quienes la rodeaban con su habilidad para hablar una gran cantidad de idiomas. En este pasaje, se asocia la palabra hermeneus, «traducton», con Cleopatra. El 
análisis de todas las apariciones de hermeneo en el corpus de Plutarco revela cómo, en la superficie, la asociación de Cleopatra con la figura del traductor refuerza su reputación como mujer fatal, aunque esta asociación apunta a un personaje tridimensional que se resiste a los límites bidimensionales de los relatos escritos existentes. —Incluido el de Plutarco.

Palabras clave: traducción, traductores, hermeneo, Cleopatra, Plutarco, estudios de género

Fecha de recepción: 25 de octubre de 2021.

Fecha de aceptación: 9 de diciembre de 2021.

Cómo citar: Myers, Bess R. H. (2021): «Cleopatra’s translational powen», en Actio Nova: Revista de Teoría de la Literatura y Literatura Comparada, monográfico 5: 122-140.

DOI: https://doi.org/10.15366/actionova2021.m5.006 
He who teaches a woman letters does not do well; he feeds more poison to a frightful asp.

- Menander, fragment $702 \mathrm{~K}$, trans. Allinson From 1921 Loeb edition of Menander: The Principal Fragments

\section{INTRODUCTION}

The above epigraph from the fourth century BCE is likely from a lost comedy by Menander. We don't know the context, but it seems to me a cheeky warning. Embedded in the fragment are a number of venomous associations: women with snakes, knowledge with poison, and educated women in particular with harbingers of danger and death. Of course, the above is just a fragment, but its gnomic nature assumes a universal relevance. The asp, who in the maxim is woman's animal counterpart, has often been associated with Cleopatra VII, said to have died from a voluntary bite from the poisonous snake. This story's validity is questionable. The power of the image, however, has survived ${ }^{1}$. If we view Cleopatra's mythical death through Menander's aphorism, then Cleopatra is both the poisonous biter and the poisoned bitten, the frightful asp fed toxic words who dies by her own fangs. She is an ouroboros, personified.

The image of the asp in Menander's fragment becomes all the more potent when we consider Cleopatra's knowledge of languages, the letters (grammata) the playwright mentions. This language knowledge was attested, albeit unreliably, by second-century Greek writer Plutarch in his biography of Mark Antony, the Life of Antony. According to Plutarch:

When Cleopatra spoke, there was sweetness in her voice, and her tongue, like some many-stringed instrument, effortlessly glided into whatever language she desired. There were few times she required a translator [di' hermeneos] when meeting with foreign peoples, and with the majority she offered her replies autonomously [di' hautes], including with the Ethiopians, Troglodytes, Hebrews, Arabians, Syrians, Medes, and Parthians. It is said that she knew the languages of many other peoples, unlike the Egyptian kings before her, who had not even attempted to learn the Egyptian language, and some who had even abandoned their own Macedonian tongue 2 . (Plutarch, 1920: 27.3-4)

\footnotetext{
${ }^{1}$ See Gurval, 2011.

2 Translations are my own, based on the Greek in the dual Greek-English editions cited throughout.
} 
Since he lived centuries after Cleopatra died from the purported snake bite, Plutarch's account of Cleopatra's language knowledge-indeed, his entire account of her life-is dubious. I am not primarily concerned in this essay with the truth-value of Plutarch's account, but rather, with his association of Cleopatra with the word bermeneus, «oral interpreter» or «translator» ${ }^{3}$. This term appears infrequently in ancient Greek texts and reads here somewhat strangely. Plutarch does not say that Cleopatra herself is a bermeneus, though the word hermeneus is closely associated with her in parallel grammatical structure: she speaks through herself (di' hautes) rather than through a translator (di' hermeneos), suggesting that she is the translator of her own words. I have always been struck-as though bitten, perhapsby the peculiarity of this introduction to Cleopatra, and I suspect that Plutarch embedded critical information about her character in this passage. For the remainder of the Life of Antony, Cleopatra's knowledge of languages is not mentioned nor does the word hermeneus appear again.

When Plutarch introduces us to Cleopatra, the then-future queen of the Ptolemaic kingdom, he notes that she was not in possession of the sort of beauty that dazed people when they saw her, though she held those who met her with the «inescapable grip» of her speaking abilities (1920: 27.2). In the Loeb edition of the text, Bernadotte Perrin translates haphen...aphukton as «irresistible charm», but the noun haphe, «touch» or «grip», suggests a physical interaction (Plutarch, 1920: 27.2). In his Life of Pericles, Plutarch uses the same word, baphe, in a metaphor for rhetoric: Pericles, the Athenian statesman and general, «showed that rhetoric is, as Plato says, the capability of leading the soul [psychagogia], and that its greatest concern is the investigation of dispositions and passions, which are like the strings and stops of the soul and demand a very delicate touch [mal' emmelous haphes] to play» (Plutarch, 1916a: 15.4). It is as though to speak through a translator removes the speaker, physically and metaphorically, from her audience, so that they are too far away to grasp or touch. To speak di' hautes, «through herself», allows for the kind of closeness and intimacy necessary for

\footnotetext{
${ }^{3}$ In this essay, I render hermeneus as «translator» rather than «interpreter». While the former usually refers to oral translation and the latter written translation, this is not a hard-and-fast rule, and both words describe someone who translates from one language to another. The medium in which one translates is less important to our understanding of Cleopatra's «hermeneutic» power than the fact that she mediates between and among languages and peoples. I also use the word «translator» for hermeneus to distinguish an interpreter of languages with an interpreter of signs and omens. Additionally, I use the present tense to describe Cleopatra's actions in Plutarch's text, since his depiction of her is more akin to a literary character than a historical person.
} 
Cleopatra's asp-like activity. This closeness puts Cleopatra at risk of poisoning both her audience and herself.

The tactile aspect of haphe invites us to linger on the asp allegory and the venom for which asps were known. Philostratus, a Greek sophist who lived a generation after Plutarch during the Roman Empire, wrote in his Lives of the Sophists that Philostratus the Egyptian, a sophist (and no relation to Philostratus, author of the Lives), had studied philosophy with Cleopatra (Philostratus, 1921: 1.5). The author attributes Philostratus' ostentatious style to his association with Cleopatra, a woman «for whom the love of words itself [to philologein] was a delicacy [truphen]» (Philostratus, 1921: 1.5). Here, as in Plutarch's depiction, Cleopatra is a femme fatale who interacts even with language as though it were an erotic pleasure. However, unlike an ingested herb, such as, say, the pharmakon nepenthes, the «un-sorrowing drug» that Helen adds to wine in the Odyssey, venom requires that the predator has physical contact, however brief, with its prey (Homer, 1919: 4.220-221). Indeed, Plutarch says that Cleopatra's appearance, combined with her personality and her persuasiveness, anephere ti kentron: literally, «provided something sharp» (Plutarch, 1920: 27.2). A kentron is a pointed object, often a goad for driving animals, but is also the sharp sensation of a sting, like one from a bee or wasp. Plutarch's metaphor rooted in the phrase anephere ti kentron seems to be this: Cleopatra drew people to her, as though they had been goaded, or perhaps spurred on by a prick or a sting. The sting cannot occur without the intimacy afforded by her knowledge of languages, and the poison thus remains with the poisoner. As Menander's saying suggests, educated and knowledgeable women are fearsome, and the closer they are, the more dangerous they become. I use Menander's asp metaphor as a motivating kentron, which incites me to pursue Plutarch's use of hermeneus in the Life of Antony and its significance for our understanding of Cleopatra-at least, of his depiction of Cleopatra, as unmoored from the historical woman as she may be.

Among the difficulties of discussing Cleopatra is the question, whose Cleopatra is the subject of our study? Though undoubtably an illustrious political figure, we have nothing written about Cleopatra by Cleopatra herself, and what we do have in the way of textual accounts are unreliable at best, and malicious at worst. Shelley Haley describes the «true Cleopatra» she had studied as a Classics student as «a construction of classical scholars and the Greek and Roman authors they consulted» (Haley, 1993: 29), scholars whose discipline «has kept Cleopatra's Africanity and Blackness a secret and questionable» (Haley, 1993: 30). In rereading Cleopatra from a Black feminist perspective, Haley determines that «Classicists 
and historians have misread Cleopatra as a way of furthering ideas of racial purity and hegemony» (Haley, 1993: 30). For Mary Hamer, the story of Cleopatra has «the weight of originary myth in Western culture: and, used in metaphor, they are specially disposed to illumine the place of women in the social order»(Hamer, 1993: xvii). Vanessa Puyadas Rupérez argues that there are (at least) two Cleopatras, «Cleopatra grecoegipcia» and «Cleopatra romana», and the latter, whose seductive and insatiable image persists, «creada por Augusto y sus partidarios fue también perpetuada hasta bien entrado el siglo xx por los historiadores modernos»—in other words, «el retrato de Cleopatra creado por sus enemigos» (Rupérez, 2016: 21). The Cleopatra of Plutarch is in large part «Cleopatra romana», about whom «casi todos los testimonios que existen son literarios» (Rupérez, 2016: 25). I limit my scope in this essay to one of the principal literary sources to which Rupérez refers. Thus, in what follows, I track Plutarch's use of hermeneus to situate Cleopatra's role in the Life of Antony and the power afforded by her language abilities. What significance may we find in Cleopatra's association with the hermeneus, the translator whom she supplants? What are we to learn about Cleopatra from this list of languages and from her textual proximity to the word hermeneus? I believe that, on the surface, Cleopatra's association with the word hermeneus creates and reinforces her reputation as a femme fatale, though this association gestures to a three-dimensional character who resists the two-dimensional bounds of extant written accounts.

\section{Cleopatra's Languages}

Though Plutarch's Lives are of questionable historical authority-by his own admission, he did not write histories, but rather, «lives» (Plutarch, 1919: 1.1)—we must ask where this association of Cleopatra with language knowledge may have come from, and whether there is any significance to the languages Plutarch lists. Cassius Dio, a Roman historian writing in Greek who lived at the same time as Lives author Philostratus, gives an account of Cleopatra and her involvement with Antony in his Roman History, though he does not mention her language abilities. Of Cleopatra's downfall, he notes:

But Cleopatra was, on the one hand, of insatiable pleasure [Aphrodites], and on the other, of insatiable greed, and she was both ambitious for glory and prone to arrogance. She secured rule over the Egyptians as their queen by means 
of love and was hopeful that she would win over the Romans the same way. However, in the latter she failed, and ultimately lost the former as well. She won over two great Roman men, and caused her own downfall because of the third. (Dio Cassius, 1917: 51.15)

The two men Cleopatra «won oven» are, presumably, Julius Caesar and Mark Antony, and the third, because of whom Cleopatra «caused her own downfall», is Octavian, who as emperor of Rome took the title Augustus. Her relationships with Caesar and Antony were, at least in part, political decisions. With Julius Caesar, whom she never married, she had a son, Caesarion, and sometime after Caesar's murder in 44 BCE she began a relationship with Antony while he was still married to his fourth wife, Octavia. Eventually, Antony and Octavia divorced, and he married Cleopatra. Though Antony formed a political alliance with Octavian and Marcus Lepidus, termed the Second Triumvirate, Octavian eventually became sole ruler of Rome by defeating both Antony and his ally, Cleopatra, in the Battle of Actium in 31 BCE. Cassius Dio's summary of Cleopatra's life, as Erich Gruen underscores, represents «The Roman perspective», which, «inescapably, presents her as part of a duo, whether with Caesar or with Antony, either as being manipulated by them for their purposes or as manipulating them for hers» (Gruen, 2011: 40). However, such an account cannot do «full justice to the woman or to the circumstances in which she found herself» (Gruen, 2011: 40).

Plutarch nods to the multidimensional circumstances of Cleopatra's life in his depiction of her as multilingual, though some biographers and historians have dismissed the significance of her abilities, or have argued that these abilities never existed. According to Pliny in his Natural History, Mithridates VI (known also as Mithridates the Great, king of Pontus during the first century BCE), was also multilingual: as king of twenty-two races, he apparently declared justice in just as many languages and could speak to those over whom he ruled without a translator (Pliny, 1942: 7.24). Of Cleopatra and Mithridates, Henry Gehman stresses:

Probably very few men became expert polyglots by deliberately studying languages, although we are told that Themistocles devoted himself to a study of Persian with a definite purpose. In his day there were no grammars, lexicons, and chrestomathies, and a man who wished to study a foreign language had many disadvantages not existing in our day. The most natural way of acquiring a foreign speech was to live in a district where several tongues were spoken and where their acquisition was a necessity and was accomplished without any conscious effort. (Gehman, 1914: 18) 
Here, it is implied that Cleopatra, if she was truly a polyglot, likely made no «conscious effort» to learn the many languages Plutarch lists. However, Plutarch emphasizes how rare Cleopatra's language abilities were, because, as quoted above, «she knew the languages of many other peoples, unlike the Egyptian kings before her, who had not even attempted to learn the Egyptian language, and some who had even abandoned their own Macedonian tongue». In this way, Cleopatra stands apart from her predecessors, and her language abilities should not be dismissed as abilities that came to her without any deliberate study.

Determining what languages Cleopatra may have been taught as a child is complicated by whether historians understand her lineage as Egyptian (African), as Macedonian (Greek), or as Greco-Egyptian. Cleopatra was a descendent of Ptolemy I, a Macedonian who ruled over Egypt after the death of Alexander the Great in 323 BCE. Adrian Goldsworthy argues that Cleopatra's first language would not have been an Egyptian one, but that «Greek was her first language, and it was in Greek literature culture that she was educated»(Goldsworthy, 2010: 8)—-though we know now that Cleopatra's Egyptian identity has historically been minimized and her Greek identity amplified. Haley contends that the Greco-Egyptian Cleopatra would have had a Black ancestor, though Classics scholars have been «willing-eager-to erase the Black ancestor and claim the beautiful Cleopatra for Europe» (Haley, 1993: 29-30). Further, Haley summarizes Goldsworthy's book, Antony and Cleopatra, as «meant to reinforce long-held views of Cleopatra as Macedonian and important only because of her ties to Roman leaders, and to squash any feminist or Afrocentric notions to the contrary» (Haley, 2011: 552). Like Goldsworthy, Michael Grant also insists upon Cleopatra’s Greekness, stating that «Cleopatra VII would have described herself as a Greek», because «Whatever the racial ingredients of her Macedonian ancestors, her language, like theirs (though they had spoken a dialect), was Greek, and so was her whole education and culture» (Grant, 1972: 5). Along these lines, Goldsworthy interprets Plutarch's suggestion that the Egyptian kings before her «had not even attempted to learn the Egyptian language, and some...had even abandoned their own Macedonian tongue» to imply that Cleopatra did, in fact, learn the Egyptian language, and perhaps even learned her family's Macedonian dialect; thus, he suggests that «Cleopatra herself was the first of the family able to speak the Egyptian language» (Goldsworthy, 2010: 20). Though stated with authority, Goldsworthy's assertation about Cleopatra's identity is uncertain, and, according to Haley, unlikely. 
The other languages listed by Plutarch include those spoken by the Ethiopians; the Troglodytes (or perhaps Trogodytes); Hebrews; Arabians; Syrians; Medes; and Parthians. Grant notes that the Ptolemies traded glass and other goods with the people of Ethiopia, and likely traded also with the Troglodytes, who «inhabited the torrid African coast from upper Egypt down to the farther end of the Red Sea» (Grant, 1972: 34). It is possible, he suggests, that Cleopatra learned these languages in her youth, in order to facilitate trade and other interactions as she grew (Grant, 1972: 34). Grant also proposes that «Perhaps she did not learn [Aramaic and one of its dialects, Syriac] as a girl, but mastered them after she had practical reasons for taking an interest in all these territories»(Grant, 1972: 141). This contradicts Gehman's point that Cleopatra could not have seriously studied so many languages, and must have acquired them unconsciously. Ultimately, it is unknown whether Plutarch's account is to be trusted, and, if we do trust Plutarch, at what point Cleopatra acquired her language abilities. However, we can be certain that such skills would have offered her a kind of intimate power when interacting with neighboring peoples and those under her rule.

\section{Translators in Plutarch's Corpus}

Since the word hermeneus appears only once in the Life of Antony, we must look elsewhere in Plutarch's corpus to get a sense of its connotations. Instances of the word hermeneus and translator figures in general are relatively rare in ancient Greek and Latin works, though we may entertain Gehman's theory that «we should not be surprised that... authors have not referred to linguists more frequently» because «affairs of everyday knowledge are those least often mentioned in books»(Gehman, 1914: 64). Rachel Mairs echoes this sentiment, arguing that translators in ancient texts are «too often invisible, mentioned only under exceptional circumstances», and further:

Like their literary counterparts, translators, oral interpreters tend not to receive recognition for their role, or acknowledgement of their authorship of the translated utterance they create. Where their role is recognized, their purpose is usually considered to be the production of a fluent, transparent text or speech that does not signpost itself as a translation. There are many reasons why this may be so, which most likely differed from case to case in the ancient world. Unless engaged in an additional diplomatic, administrative, or commercial role, the interpreter's linguistic knowledge is seldom regarded as a professional 
accomplishment in and of itself. It may be inconvenient or even embarrassing to mention that an interpreter has been used. Those historians who recount complex military engagements and diplomatic machinations between groups who speak different languages, for example, can be forgiven for not constantly punctuating their narrative with references to interpreters. Absence of evidence is not evidence of absence. (Mairs, 2011: 66)

That Cleopatra acts as her own bermeneus makes visible work that was (and is) often invisible. The mention of translators in Plutarch's works, then, though translators were likely present in day-to-day life, is unusual and potentially significant. Appearances of translators in Plutarch's corpus are thus valuable for parsing Cleopatra's association with the word hermeneus.

The association of hermeneus figures with deceit long appears long before Plutarch's use of hermeneus in the Life of Antony. In Plato's Cratylus, for example, Plato connects the root of hermeneus to a folk etymology of the Greek god Hermes' name, a god known for his cunning and deceit. Though Plato predates Plutarch by a couple of centuries, Plutarch was a Platonist very familiar with the philosopher's dialogues. In the Cratylus, Cratylus, Hermogenes, and Socrates discuss the appropriateness of names and their relationships to the people or objects they represent. Hermogenes asks Socrates to explain the origin of the name «Hermes», a messenger god and a trickster. Socrates explains:

Well, this name, «Hermes», seems to have something to do with speech, as Hermes is both an interpreter [hermenea] and a messenger, both thievish and deceptive in his speech, and facilitates dealings between merchants and customers. ${ }^{4}$ All these matters concern the power of speech. Now then, as I said before, the word eirein refers to the use of speech, and further, Homer often uses the word emesato, which means «to devise». From both of these words, the lawgiver compels us to use the appropriate name for this god, the god who devised speaking and speech itself—for eirein means «to speak»—and says: «You humans, the one who devised speech should be called Eiremes by you». We made the name more beautiful-sounding (to our ears, anyway), and now call him «Hermes». (Plato, 1926: 407e-408b)

Though employing speech does not necessitate that one is deceptive, it is telling that these concepts are closely linked within Hermes' character, and thus with the word bermeneus.

\footnotetext{
4 The word used here is agorastikon, «related to the agora», which was the public marketplace. The suggestion here seems to be that Hermes aided in commerce by facilitating communication between sellers and buyers.
} 
The word hermeneus and translator figures appear nine times in Plutarch's works: three times in his Life of Themistocles; twice in the Life of Marcus Cato; and once each in the Life of Sulla, Life of Artaxerxes, Life of Antony, and the Virtues of Women. They are most often unsympathetic, immoral, or ineffective characters. In his Life of Themistocles, for example, Plutarch mentions Epicydes, a demagogue who spoke powerfully (deinon men eipein) but had a feeble soul (malakon de te psyche) and was susceptible to bribes (Plutarch, 1914: 6.1). The word malakos may refer to softness or a gentle manner, but also may mean «morally weak» or «effeminate». In order to prevent Epicydes from becoming the general of the Athenian army, Themistocles, an Athenian general himself, devised a plan:

If authority were handed over to Epicydes, Themistocles feared that Athens would be completely ruined, so he decided to appeal to Epicydes' ambition by bribing him. Ultimately, the way he dealt with the double-tongued man [ton diglosson] was praised: when Epicydes arrived alongside representatives sent by the Persian king demanding offerings of earth and water, the translator [hermenea] was seized by decree. He was subsequently put to death because he dared use the Hellenic voice [phonen] to deliver barbarian commands. (Plutarch, 1914: 6.1-2)

Plutarch refers to Epicydes as both a translator and as a «double-tongued» man. Diglossos, literally «one who speaks two languages», may refer to Epicydes’ bilingualism, but also underscores his deceitfulness. Indeed, Epicydes communicates out of both sides of his mouth, so to speak, negotiating with the Persians while appearing to support the Athenians. The final contrast here between the Greek and Persian languages is significant: the diglossos is put to death for daring to deliver «barbarian» (i.e. Persian, or more generally non-Greek) commands in his own Greek voice. The folk etymology of barbaros, «barbarian», is said to derive from the nonsensical sound of non-Greek languages to ancient Greek speakers. Epicydes' deceit is amplified by the fact that he has translated the demands of a non-Greek leader into the Greek language. Though the word diglossos does not necessarily refer to a dishonest person, its use in reference to Epicydes suggests that deceitfulness was, by Plutarch's time, intertwined with idea of a hermeneus. Here also the double-tongued-ness of the translator perhaps reminds one of the split-tongued, venom-mouthed asp. Variants of hermeneus appear twice in a later episode of the Life of Themistocles. After his exile from Athens, the title figure meets with the Persian king, whom we are told by Plutarch was either Xerxes or his son, Artaxerxes (Plutarch, 1914: 27.1). During this meeting, Themistocles speaks through a translator, and Themistocles is ironically both a Hellene speaking Greek, unable 
to communicate with the Persian king himself, and a Greek outcast, sent away from his Greek city of origin (Plutarch, 1914: 28.1).

The word bermeneus appears also in Plutarch's Life of Marcus Cato when a translator is used to intentionally separate speaker from audience. Cato the Elder-as he is often called to distinguish him from his great-grandson, Cato the Younger-was a Roman citizen who served in the Second Punic War and was later elected consul and censor. As censor, he managed the census and helped to determine and control the Roman mores, their social norms and customs. Cato famously and staunchly opposed Greek influence on the Roman way of life, and Plutarch attests to this:

Cato also spent a lot of time in Athens. It is said that a certain speech of his has endured, a speech which he delivered to the Athenian people in Greek. In it, he supposedly praised the virtue of the ancient Athenians and said he was enchanted by their great and beautiful city. This story, however, is fictitious. In truth, he engaged with the Athenians through a translator [di' bermeneos], though he was able to speak with them himself. He held strong to his customs and instead derided those who marveled at anything Greek. (Plutarch, 1914: 12.4)

Instead of speaking in Greek to the Athenians, though he was able to do so, he insisted upon speaking Latin in order to display his dedication to his Roman customs. For Cato, the bermeneus was a protective figure that literally and figuratively separated him from the Greeks. His choice to rely on a translator also underscores how language functions an essential cultural marker. Unlike Epicydes, whom Plutarch suggests took on «barbaric» qualities by performing a non-Greek language, Cato remained «fully» Roman by speaking in Latin, reminding both himself and his audience of his conservative mores and anti-Greek political position. According to Plutarch, Cato further essentializes Greek and Romans:

...the Athenians marveled at the speed and specificity of his speech: what he said briefly, the interpreter took much longer to report and used many more words. On the whole, [Cato] thought for Athenians that their words came from their lips, while for Romans, they came from their hearts. (Plutarch, 1914: 12.5)

According to Cato, Roman language use reflected their directness and authenticity, while Athenian loquacity indicated insincerity-Athenians were all talk, so to speak.

In his Life of Sulla, a translator appears when Plutarch recounts an anecdotal exchange between Sulla, a Republican-era Roman general and twice-consul, and a half-man, half-beast satyr, who is taken captive in a sacred area called the Nymphaeum: 
It is here, they say, that a satyr was taken while asleep, the sort of satyr that sculptors and painters depict in their artwork. The satyr was taken to Sulla and asked through many translators [di' hermeneon pollon] who he was. The satyr could hardly utter a single intelligible word, but instead produced a harsh vocalization [trakheian...phonen], like a mix of a neighing of a horse and the bleating of a goat. Sulla was shocked and sent the satyr away. (Plutarch, 1916b: 27.2)

The word trakheian, «rough» or «harsh», describes the phonen, which may alternately be translated as a «sound» or as «utterance». The satyr's voice may have sounded rough, because it was similar to the sounds of animals, or, as Gehman suggests, the satyr could not be understood because his accent was «harsh»(Gehmn, 1914: 21). The satyr, a hybrid character with the features of both a man and of a goat, is a barbaric, animalistic, and uncivilized figure. Whether the (likely fictional) satyr spoke a known language with a «harsh» accent, or an unknown non-human language, his language was so obscure that it could not be translated, and his utterances were so offensive that Sulla sends him from his presence. In this case, the foreigner literally possesses animalistic qualities, and none of the many interpreters is able to relate his noises by means of human speech.

In the Life of Artaxerxes, it is not a hermeneus who is deceptive, but rather, a deceptive person who claims to be a translator. In his biography of the king of the Persian Empire and son of Xerxes I, Plutarch narrates the manner by which the death of Cyrus the Younger, a Greek, at the Battle of Cunaxa in $401 \mathrm{BCE}$ was reported to Artaxerxes. According to Plutarch, Ctesias, a Greek historian, insisted that he himself had been sent to help negotiate with the Greeks after the battle, though it is suspicious that Xenophon, author of the Anabasis, never mentions his name. Plutarch refers to Ctesias' story as an «obvious lie» (lampron...pseusma) because, if Ctesias had indeed «come along as a translator (bermenea) during such significant conversations, then [Xenophon] would not have left him nameless» (Plutarch, 1926: 13.3-4). This appearance of bermeneus is unlike its use elsewhere in Plutarch's works. Perhaps relying on Mairs' point above that «historians who recount complex military engagements and diplomatic machinations...can be forgiven for not constantly punctuating their narrative with references to interpreters», Ctesias presumably says he was a translator because the translator's presence is least likely to be recounted by historians.

In the Virtues of Women, a segment from his Moralia, Plutarch narrates an incident concerning the women of Salamantica, a city besieged by Hannibal in the second century BCE. The citizens of Salamantica agreed to leave the city along with the people they enslaved 
in exchange for their safety. Though the men were searched as they left the city, the women suspected they would not be searched and smuggled weapons beneath their clothing. When the Masaesylian soldiers commanded to guard the people of Salamantica leave their posts to plunder the city alongside Hannibal's forces:

the women called to the men and handed over the swords they had smuggled, and some women even attacked the guards. One woman took hold of the spear of the translator [bermeneos], Banon, and managed to strike him, but it so happened that he was protected by a breastplate. (Plutarch, 1931:10)

This episode is of particular interest because Plutarch mentions only one would-be victim by name: that of Banon, the interpreter. Though Mairs asserts that Banon was "“collateral damage," killed with his own spear», the text itself suggests that the interpreter survived because he happened to be wearing a breastplate for protection (Mairs, 2011: 68). Either, as Mairs suggests, Banon was killed dishonorably by the Salamantican women, or he narrowly escapes; in any case, he is not a particularly noble character, as it would not have been considered particularly noble to be killed (or almost killed) by a group of women.

After taking all appearances of the word hermeneus in Plutarch's corpus into account, it is possible to track certain patterns. Some instances of bermeneus fall into the category of «translator as traitor», though not all. Plutarch certainly presents translators that are deceitful, such as Epicydes, or expendable, such as Banon, or people who use translators for their own deceit, such as Ctesias. Even one's use of a translator is notable, as the episode with Cato suggests. His use of a translator so as to avoid speaking Greek, though he is able, reminds us that translators may be used as tools to manipulate an audience. Sulla's reaction to the satyr's voice and the translators' inability to render the satyr's language into Latin, whether he had an unfamiliar accent or simply sounded like an animal, reinforces the xenophobic notion of foreigner- or barbarian-as-animal. The instances of bermeneus in the story of Themistocles also associate the translator with a barbarian/Greek dichotomy. Though it is not clear yet whether Plutarch had an agenda when using hermeneus in the Life of Antony, his body of work suggests that translators do not participate in entirely safe or honest work. 


\section{THE HERMENEUS AND THE ASP}

The word bermeneus connoted cunning, deceit, danger, and mystery on the one hand, and reliability, certainty, and necessity on the other. By placing Cleopatra in close proximity to the word bermeneus and emphasizing her ability with languages, Plutarch at once exoticizes and familiarizes her, and makes visible work that is most often invisible. As her own translator, she is able to function in political and social situations by herself rather than relying on others, which foreshadows both her remarkable life and her tragic death.

We return, then, to the asp, and to Menander's comparison of women with venomous snakes, filled with poisonous words. Plutarch describes Cleopatra's death in this way:

Some say that the asp was brought in with the figs and leaves, hidden underneath from the start-for this was what Cleopatra had ordered-so that the poisonous animal would attach itself to her without her realizing it. But when she removed some of the figs, she spotted it and said, «Oh, there it is», and held out her naked arm for the impending bite. Others say that the asp was carefully placed in a water jar, and while Cleopatra poked at it and provoked it with a gold distaff, it jumped out of the jug and clung to her arm. But the truth is that no one knows for sure. (Plutarch, 1920: 86.1-2)

Oudeis oiden: no one knows. We do not know how Cleopatra died, either Plutarch's fictional version or the historical figure. That much is true. But regarding the former, her association with bermeneus and her knowledge of languages, when considered alongside the above quotation, introduces an ominous subtext. We are told early that Cleopatra's voice is like an instrument, and that she speaks any number of languages with ease. However, as Anne Carson makes clear, «Putting a door on the female mouth has been an important project of patriarchal culture from antiquity to the present day», and that its «chief tactic is an ideological association of female sound with monstrosity, disorder, and death» (Carson, 1995: 121). That Cleopatra's voice may sound like a beautiful instrument does not preclude it from also being monstrous: in this respect, we are reminded of the Sirens, monsters with beautiful voices who causes destruction and death when men sail too close.

However, it is not simply the mouth on a woman's face that must be shut tight. According to Carson, Plutarch famously makes a connection «between verbal and sexual continence, between mouth and genitals»(Carson, 1995: 130), which reinforces how women's «two mouths» (Carson, 1995: 131) must be kept closed. Indeed, Carson notes that 
the image of a «leaky water jar»—an image which is «one of the commonest figures in ancient literature for the representation of female sexuality», and which Plutarch himself employs in a section of the Moralia about talkativeness (Carson, 1995: 131)—recalls the episode quoted above of Cleopatra agitating the asp. In this way, chastity and silence involve the same action: the closing of a mouth. Though he initially presents Cleopatra in complimentary terms, his use of hermeneus ultimately suggests that she could not «keep her mouths closed», and perhaps was to blame even for her own death.

The presence of hermeneus in close proximity to Cleopatra in the Life of Antony alludes to a multifaceted historical figure to whom we do not have direct access, while also gesturing to a complex web of meaning embedded in the word bermeneus itself. My hope is that we may use this proximity as a kentron, which motivates us to expand our understanding both of the place of translators in the ancient world, and of Cleopatra and the powerful «poisonous words» for which she was known. 


\section{BIBLIOGRAFÍA}

Carson, Anne (1995): «The Gender of Sound», in Glass, Irony, and God, New York, New Directions: $119-142$.

Dio Cassius (1917): Roman History, Volume VI: Books 51-55, translated into English by Earnest Cary and Herbert B. Foster, Cambridge, Harvard.

Gehman, Henry Snyder (1914): The interpreters of foreign languages among the ancients; a study based on Greek and Latin sources (Diss., University of Pennsylvania), Lancaster, Intelligence Printing Company.

Goldsworthy, Adrian (2010): Antony and Cleopatra, New Haven, Yale University Press.

Grant, Michael (1972): Cleopatra, New York, Simon and Schuster.

Gruen, Erich S. (2011): «Cleopatra in Rome: Facts and Fantasies», in Margaret M. Miles (ed.): Cleopatra: A Sphinx Revisited, University of California Press, Berkeley: 37-53.

Gurval, Robert A. (2011): «Dying Like a Queen: The Story of Cleopatra and the Asp(s) in Antiquity», in Margaret M. Miles (ed.): Cleopatra: A Sphinx Revisited, Berkeley, University of California Press: 54-77.

Haley, Shelley P. (1993): «Black Feminist Thought and Classics: Re-membering, Re-claiming, Re-empowering», in Nancy Sorkin Rabinowitz and Amy Richlin (eds.): Feminist Theory and the Classics, New York, Routledge: 23-43.

Haley, Shelley P. (2011): «Review of Antony and Cleopatra», in The Classical Review, 61.2: 552553.

Hamer, Mary (1993): Signs of Cleopatra (History, politics, representation), London, Routledge.

Homer (1919): Odyssey, Volume I: Books 1-12, translated into English by A. T. Murray, revised by George E. Dimock, Cambridge, Harvard.

Mairs, Rachel (2011): «Translator, Traditor: The Interpreter as Traitor in Classical Tradition», in Greece \& Rome, 58.1: 64-81.

Philostratus (1921): Lives of the Sophists. Eunapius: Lives of the Philosophers and Sophists, translated into English by Wilmer C. Wright, Cambridge, Harvard.

Plato (1926): Cratylus, Parmenides, Greater Hippias, Lesser Hippias, translated into English by Harold North Fowler, Cambridge, Harvard.

Pliny (1942): Natural History, Volume II: Books 3-7, translated into English by H. Rackham, Cambridge, Harvard. 
Plutarch (1914): Lives, Volume II: Themistocles and Camillus, Aristides and Cato Major, Cimon and Lucullus, translated into English by Bernadotte Perrin, Cambridge.

Plutarch (1916a): Lives, Volume III: Pericles and Fabius Maximus, Nicias and Crassus, translated into English by Bernadotte Perrin, Cambridge, Harvard.

Plutarch (1916b): Lives, Volume IV: Alcibiades and Coriolanus, Lysander and Sulla, translated into English by Bernadotte Perrin, Cambridge, Harvard University Press.

Plutarch (1919): Lives, Volume VII: Demosthenes and Cicero, Alexander and Caesar, translated into English by Bernadotte Perrin, Cambridge, Harvard.

Plutarch (1920): Lives, Volume IX: Demetrius and Antony, Pyrrbus and Gaius Marius, translation into English by Bernadotte Perrin, Cambridge, Harvard.

Plutarch (1926): Lives, Volume XI: Aratus, Artaxerxes, Galba, Otho, translated into English by Bernadotte Perrin, Cambridge, Harvard.

Plutarch (1931): Moralia, III: Sayings of Kings and Commanders, Sayings of Romans, Sayings of Spartans, The Ancient Customs of the Spartans, Sayings of Spartan Women, Bravery of Women, translated into English by Frank Cole Babbit, Cambridge, Harvard.

Rupérez, Vanessa Puyadas (2016): Cleopatra VII: La creación de una imagen (Representación publica y legitimación política en la Antigüedad), Zaragoza, Prensas de la Universidad de Zaragoza. 


\section{SOBRE LA AUTORA}

\section{Bess R. H. Myers}

Lecturer, Department of English, University of Illinois Urbana-Champaign.

$\mathrm{PhD}$, Comparative Literature, University of Oregon (2019).

Reseach interest: Ancient Greek and Roman rhetorics, history of rhetoric, classical reception, Plato's Timaeus, translation studies.

Highlighted Publications: Myers, B. R. H. (2021). Platonic Synergy: A Circular Reading of the Sophist and Timaeus. Journal for the History of Rhetoric, 24(3), 251-273.

https://doi.org/10.1080/26878003.2021.1975464

Recent Publications: Myers, B. (2021). Akairos. In M. Kennerly (Ed.), A New Handbook of Rhetoric: Inverting the Classical Vocabulary Penn State University Press. Myers, B. R. H. (2021). Platonic Synergy: A Circular Reading of the Sophist and Timaeus. Journal for the History of Rhetoric, 24(3), 251-273. https://doi.org/10.1080/26878003.2021.1975464. Myers, B. (2021). Review of Jenny Rice's Awful Archives: Conspiracy Theory, Rhetoric, and Acts of Evidence. Enculturation. http://enculturation.net/review-awful-archives. Myers, B. (2020). Review: R. Kaster's Cicero: Brutus and Orator. Bryn Mawr Classical Review, 2020.12.20. https://bmcr.brynmawr.edu/2020/2020.12.20/

Contact information: email: brhmyers@illinois.edu 